\title{
The Effect of Leadership Task Behavior and Relational Behavior on Job Performance: Investigating the Moderating Role of Work Alienation
}

\author{
Wenchen Guo, Rong Dai, Jing Yang \\ Faculty of Management and Economics, Dalian University of Technology, Dalian, China \\ Email: guowch@dlut.edu.cn, dairongstyle@126.com
}

Received 3 March 2016; accepted 27 March 2016; published 31 March 2016

Copyright (C) 2016 by authors and Scientific Research Publishing Inc.

This work is licensed under the Creative Commons Attribution International License (CC BY). http://creativecommons.org/licenses/by/4.0/

\section{(c) (7) Open Access}

\begin{abstract}
When the new career, the feature of which was boundaryless career attitudes, organizational mobility preference, self-directed and values-drive had appeared in employees, the new subject of the current academic and organizational practices faced was what actions the leader should take to guide the behavior of employees effectively, even to improve job performance. On the basis of reviewing the existing literature, a theoretical framework of leadership task behavior and relational behavior, work alienation and job performance had been proposed in this study by using leadership behavior theory. Questionnaire data were collected from employees by paired data and analysis data using SPSS17.0 LISREL8.7. Regression analyses revealed insignificant relationships between the leadership task behavior, relational behavior, and job performance, and work alienation partially mediated this relationship. This study not only enriches the theory of leadership behavior, but also has a guide and reference for the leadership and management practices of enterprises.
\end{abstract}

\section{Keywords}

Leadership Task Behavior, Leadership Relational Behavior, Work Alienation, Job Performance, Empirical Analysis

\section{Introduction}

After the 1970s, protean career [1] and boundaryless career [2] appeared gradually, and the most prominent fea

How to cite this paper: Guo, W.C., Dai, R. and Yang, J. (2016) The Effect of Leadership Task Behavior and Relational Behavior on Job Performance: Investigating the Moderating Role of Work Alienation. Journal of Service Science and Management, $\mathbf{9}$, 97-110. http://dx.doi.org/10.4236/jssm.2016.92013 
ture is that there are a growing number of employees with boundaryless career attitudes, organizational mobility preference, self-directed and values-driven career attitudes [3]. Organizations don't commitment lifetime employment any longer, which leads workers to face unemployment risk at any time, and thus it results in the decrease of employee's loyalty and personal commitment to the firm replaced by organizational commitments [4]. In this case, the employees focus more on the job, as well as their psychological feelings about the factors associated with work. There will be work alienation when factors about the work can't meet the expectations of employees [5], that is, the employees may feel to work out of control, and can't find the meaning of work, then their work motivation may decline as well, which will lead to work engagement reduced and other negative attitudes and behaviors. Study shows that work alienation is becoming a common phenomenon increasingly [6]. The main factors influencing work alienation is from leading factors [7]. Based on theory of motivation, when work can't meet the employees' expectations and makes employees have sense of work alienation, they will reduce the work motivation, and then perform less work engagement and low work enthusiasm. Studies have shown that employees' work alienation will result in less performance of organizational citizenship behavior (OCB), and will even cause counterproductive behavior like alcoholism, which is harmful for job performance and organizational performance.

Most of previous studies about the influence of leadership behavior on job performance are based on the theory of psychological contract and organizational commitment, and from the standpoint of the exchange of material and spiritual between employee and organization, and between employee and leadership. But the emergence of protean career and boundaryless career changes traditional concept of employment and psychological contract, and it also puts forward a new subject for leadership behavior, organizational behavior, and even the management practice of enterprise organization, that is in the new organization environment what leadership and management behavior the leaders take will effectively guide employees' behavior to improve job performance. Therefore, based on the theory of motivation and behavior and from the perspective of employees paying more attention to the work itself and the future career development, this paper proposes the relational model that leadership task behavior and relationship behavior will affect job performance through work alienation, and then the paper confirms that the leadership task behavior and relationship behavior is how to influence work alienation (individual attitudes and behavior), then influence the job performance. This study not only enriches the theory of leadership behavior, but also has guidance and reference value for enterprise leadership and management practices.

\section{Theoretical Background and Hypotheses}

\subsection{The Relationship of Leadership Task Behavior, Relational Behavior with Job Performance}

Leadership is the process that has a certain influence in a group, and can lead the group to achieve goals through the kind of influence [8]. Therefore, from the perspective of the definition of leadership, one of the functions of leadership is to improve job performance and organizational performance by all means. Leadership task behavior contributes to reaching the goal: it can help group members to achieve their goals, and it emphasizes the technology and production of the work. The leader performing task behaviors will inform the team members what should do, and set performance standards for them. However such leaders see employees as a tool for achieving goals, that is they just care about the employee's target achievement rather than employees' personal feelings, which leads employees feel no enterprise's attention and can't integrated into the enterprise, so it is hard for these employees to put themselves into work completely and dutifully [9], which becomes the obstacle for the completion of task performance. At the same time, employees are not willing to attach themselves to organization with lower organizational identification, which is bad for the performance of employee relations [10]. Leader's relational behavior provides a good interpersonal relationship and atmosphere for subordinates to make them feel comfortable, which is similar to employee orientation studied by University of Michigan and Ohio State University. Bowers and Seashore (1966) defined employee orientation that a supervisor "feels that the "human relations" aspect of the job is quite important; and that he considers the employees as human beings of intrinsic importance, takes an interest in them, and accepts their individuality and personal needs” [11]. Leader's concern for employees and thinking the relationship with subordinates highly make it easier for leader to form a good relationship with employees. According to social exchange theory, employees especially Chinese employees [12] are more inclined to complete the work carefully and even make extra constructive organizational behaviors such as OCB in return [13], that is working out higher job performance [14]. In addition, under leadership relational behavior the long- 
term and frequent interaction and communication between leader and employees help employees collect relevant information to promote the understanding of each other [15]. At the same time, the concern, fairness and publicity show by the leader with relational behavior are beneficial to employee's emotional attribution which will make employees relied on organization and increase the emotional connection of organization and employees [16]. In consequence, affective commitment will be generated more easily. The affective commitment will promote employees to complete the task better by social exchange and to perform more out-role constructive organizational behavior, etc., and is conducive to the improvement of performance.

Based on this discussion, the following hypotheses are advanced.

H1 Leadership task behavior will be negatively related to job performance, it contains 3 secondary hypotheses:

H1a Leadership task behavior will affect employees' task performance negatively;

H1b Leadership task behavior will affect employees' interpersonal facilitation negatively;

H1c Leadership task behavior will affect employees' job dedication negatively.

H2 Leadership relational behavior will be positively related to job performance, it contains 3 secondary hypotheses:

H2a Leadership relational behavior will affect employees’ task performance positively;

H2b Leadership relational behavior will affect employees' interpersonal facilitation positively;

H2c Leadership relational behavior will affect employees' job dedication positively.

\subsection{The Relationship of Leadership Task Behavior, Relational Behavior with Work Alienation}

Leadership task behavior focuses on achieving goals. The leader with task behavior will clearly tell employees what they should do, and make plans to tell employees how to work, and provide employees suggestions on how to solve problems. Therefore, the leader performing task behavior will provide employees with close guidance which will make employees feel their working process and results out of control and feel no interest and significance of work, then resulting in work alienation [17]. Task behavior is task-oriented, setting performance standards for employees and encouraging staff to work efficiently, as a result the high level of job demands [18] as well as process supervision [19] will make employees emotional exhaustion and job burnout, and feel no value and significance of the work, resulting in work alienation.

The leader with relational behavior will actively communicate with employees and the communication about organization and environment variables between leader and employees is the primary way of guiding employees' expected correctly and reducing work alienation [20]. The leader with relational behavior cares about employees' sense of personal happiness, and let them get along well and comfortable. The good interpersonal relationship helps reduce work alienation [21].

Based on this discussion, the following hypotheses are advanced.

H3 Leadership task behavior will be positively related to work alienation, it contains 3 secondary hypotheses:

H3a Leadership task behavior will affect employees’ monotonousness positively;

H3b Leadership task behavior will affect employees' powerless positively;

H3c Leadership task behavior will affect employees' nihilism positively.

H4 Leadership relational behavior will be negatively related to work alienation, it contains 3 secondary hypotheses:

H4a Leadership relational behavior will affect employees’ monotonousness negatively;

H4b Leadership relational behavior will affect employees' powerless negatively;

H4c Leadership relational behavior will affect employees’ nihilism negatively.

\subsection{The Relationship of Work Alienation and Job Performance}

Work alienation is the monotonousness, powerless and nihilism of employees whose work expectation can't be met. Work alienation will result in the change of employees' emotion, attitude and behavior.

When people believe that to a certain extent they can take some control, they are more likely to perform positive emotion to respond to the environment and make proactive adjustments [22]. However, employees with work alienation generally lack the sense of control of their work and the results of environment interaction [23], resulting in disincline for any positive response to the environment. What's more, Bulter (2005) [24] believed that employee's lack of job control will result in negative spillover. Negative emotion may be negatively related to citi- 
zenship behavior (Bateman and Organ, 1983) [25], and anger, and other negative emotions will affect job performance negatively (Robinson, 1996) [26].

Employee's work alienation affects job attitude mainly reflected in the job burnout (Powell, 1994) [27], job satisfaction, organizational commitment (Hirschfeld, Field and Bedeian, 2000) [28], job engagement (ArmstrongStassen, 2006) [29] and so on. And such aspects as job burnout, job satisfaction, organizational commitment and work engagement will influence job performance significantly (Salanova, Agut and Peiro, 2005) [30].

The work efficiency of employees with job alienation will be declined (Huang, 2006) [31], which will influence task performance. Employees with work alienation will also reduce OCB, whereas OCB is the main content of the relationship performance.

Above all, the following hypotheses are advanced.

H5 Employee's work alienation will be negatively related to job performance, it contains 9 secondary hypotheses:

H5a Employee's monotonousness will affect job performance negatively;

H5b Employees' powerless will affect job performance negatively;

H5c Employees’ nihilism will affect job performance negatively.

\subsection{The Relationship of Leadership Task Behavior, Relational Behavior, Work Alienation with Job Performance}

Kanungo (1992) [32], who is the authoritative scholars in the field of work alienation pointed out, compared with the organizational structure, work characteristics and other factors, the interaction between the staff and leadership in their daily work and the style of leadership of the management have more significant influence on work alienation. DiPietro and Pizam (2008)'s [33] study results indicated that employees' alienation was unequally distributed among the restaurants within the sample, therefore possibly suggesting that work alienation is not necessarily caused by the technology employed and/or the nature of the jobs but rather by the managerial styles and practices in each restaurant. Sarros et al. (2002) [17] have shown that transformational leadership was associated with lower work alienation, whereas transactional leadership was associated with higher work alienation. Organizational structure was not significantly predictive of work alienation, but was negatively associated with transformational leadership and positively associated with transactional leadership. The significant indirect effects between organizational structure and work alienation, and between organizational structure and transformational leadership, provide further evidence that the leadership style of the organization has a more significant impact on feelings of work alienation than antecedent conditions such as organization rigidity.

Thus, work alienation staff is a combination of psychological and social phenomena, having been affected by all kinds of factors, such as individual, organization, job characteristics and the leadership and so on. In which, the leadership have the greatest influence on it [7]. Leadership is reflected to the leadership style, because leadership style largely determines the way we work, work process or work content, but also to a large extent determines the overall atmosphere of the staff and the atmosphere around the interpersonal organizations. Northouse (2001) [34] had divided leadership style into two dimensions: task behavior and relationship behavior.

Task behavior helps to achieve targets, it can help group members to achieve their goals. Relationship behavior helps subordinate to feel comfortable with themselves, others and their own situations. The Extent of the relationship behavior reflects the extent of the comfort of subordinates, colleagues, and the team, also reflects the degree of concern people. We can say that the leadership task behavior and relationship behavior will largely affect employees' work experience, which affects their judgement about their own needs whether to be met or not, the extent of satisfying work is reflected in the level of alienation. The level of work alienation indicates the degree of employees' needs is met, and ultimately affects the external performance of employees.

There are large number of studies have shown that work alienation and job performance are negatively correlated. Mulford and Waldner-Haugrud (1993) [35] have focuses on work alienation and publication productivity of agricultural scientists, and results indicate that work alienation is significantly negative correlated with publication productivity. Huang (2006) [31] selected high school volleyball coach in Taiwan, China as the object of study, found work alienation have a significant negative impact on job performance.

Employee performance including task performance and contextual performance is an action of employees. According motivation behavior theory, it is an action for specific performance motivation, motivation is decided by people's needs. According to Maslow's theory, people need to meet the physical needs, security needs, social 
needs, esteem needs and self-actualization needs. Whether people's needs are met all levels or not at, as well as satisfaction will affect the strength of the motivation of employees, which in turn will affect employee engagement at work, it will eventually be realized as the level of employee job performance. Work alienation was define as a "state of psychological separation from work insofar as work is perceived to lack the potentiality for satisfying one's salient needs and expectations" [5], it indicates the decline of work motivation.

Above all, the following hypotheses are advanced.

H6 work alienation will mediate the relationship between leadership task behavior and job performance; which includes nine sub-hypothesis:

H6a employee's monotony will mediate the relationship between leadership task behavior and job performance;

H6b employee's powerlessness will mediate the relationship between leadership task behavior and job performance;

H6c employee's emptiness will mediate the relationship between leadership task behavior and job performance;

H7 employee's work alienation will mediate the relationship between leadership relational behavior and job performance, which includes nine sub-hypothesis:

H7a employee's monotony will mediate the relationship between leadership relational behavior and job performance;

H7b employee's powerlessness will mediate the relationship between leadership relational behavior and job performance;

H7c employee's emptiness will mediate the relationship between leadership relational behavior and job performance.

\section{Research Design and Method}

\subsection{Conceptual Framework}

According to the relationship between leadership work behavior and relationship behavior, work alienation and job performance, we propose to mechanism model that how leadership task behavior and relationship behavior affect job performance, and work alienation will mediate the relationship between them as shown in Figure 1.

In this study, the work alienation is divided into three dimensions: monotony, powerlessness, and emptiness. The job performance is divided into three dimensions: task performance, interpersonal promotion and job dedication. The model is consisted mainly of relationship between the two levels. The first level, the relationship between the leadership task behavior, work alienation and job performance, it assumes that leadership task behavior negatively affect the dimensions of employee performance, and work alienation will mediate the relationship between leadership task behavior and job performance. The second level, the relationship between the leadership relational behavior, work alienation, and job performance, it assumes that the leadership relational behavior positively affect the dimensions of job performance, and work alienation will mediate the relationship between leadership relational behavior and job performance.

$\mathrm{H} 1$

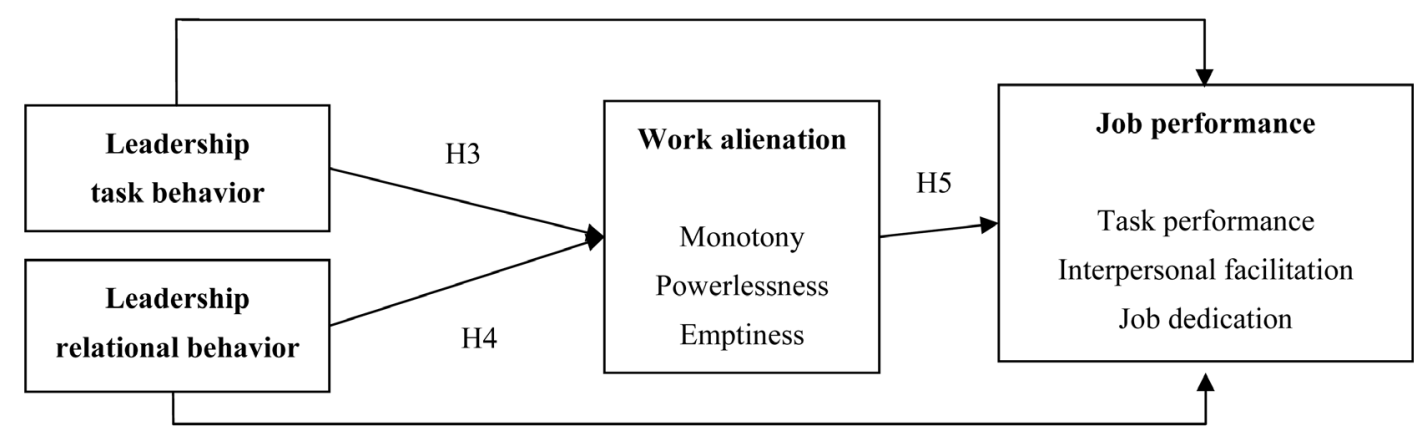

$\mathrm{H} 2$

Figure 1. Conceptual framework. 


\subsection{Measurement}

The measures utilized in the current study were chosen for two primary reasons. First, they have yielded consist ently strong reliabilities across a number of prior studies. Second, the measures tapped into the attitudes and behaviors that were relevant to the current study. A 20-item scale develop by Northouse (2012) was used to measure leadership task behavior relational behavior. Sample items of task behavior include "My immediate supervisor sets standards of performance for group members "and "My immediate supervisor develops a plan of action for the group". Sample items of task behavior include "My immediate supervisor communicates actively with group members" and "My immediate supervisor shows concern for the personal well-being of others".

Employee task performance was measured by 6-item employee task performance questionnaire developed by Tsui, Pearce and Porter (1997). Sample items include "The employee's efficiency is much higher than average" and "The employee's efficiency is much higher than the formal standards for this job". Contextual performance is consisted of interpersonal facilitation and job dedication. A 15-item scale developed by Van Scootter and Motowidlo (1996) was used to measure contextual performance. A sample for each of the two dimensions of contextual performance was "support and encourage a coworker with a problem", "offer to help others accomplish their work" (interpersonal facilitation); "volunteer for additional duty" "take the initiative to solve a work problem" (job dedication).

A 10-item scale developed by Maddi (1979) was used to measure work alienation. A sample for each of the three dimensions of contextual performance were "Those who work for a living are manipulated by those who run things", "I don’t enjoy work; I just put in my time to get paid" (monotonousness); "No matter how hard you work, you never really seem to reach you goals" (powerless); "I find it hard to believe people who actually feel that the work they perform is of value to society" (nihilism).

In the study, response options ranged from (1) "strongly disagree" to (5) "strongly agree”.

\subsection{Pretest}

In order to correct the above scale, this paper tests the reliability and validity of measures by pre-research. To avoid common method variance, the data used in this study was collected by matching samples, leadership style questionnaire is completed by the subordinate employees, their performance scale is filled by a corresponding superiors. In addition, the independent variables and dependent variables were separated in the design of the questionnaire, and the dependent variables were in the independent before, to avoid the answer to be affected by the scale of the independent. Meanwhile, in the description section of the questionnaire, we emphasized that they should fill out the questionnaire According to the free will and the actual situation in order to ensure authenticity of the data.

The questionnaire used in the study is divided into two categories, one is an employee's questionnaire, in addi tion to demographic variables: gender, education, and job, nature of business and work experience, including the scale of the leadership task behavior, leadership behavior and work alienation. One is the manager's questionnaire, including the scale of employee task performance and employee contextual performance. In this study, two types of questionnaire are numbered to ensure that the manager's questionnaire manager is matched with their subordinate's questionnaire.

The pretest of this study was conducted using a sample of managers and employees from kinds of organizations in Dalian, China. Among the participants, 103 completed surveys were returned (85.8 percent response rate).

We conducted the reliability analysis of the scale with SPSS 17.0 after the questionnaire received. The Cronbach's a coefficient of the scales is as follows: the Cronbach's a coefficient of leadership work behavior scale is 0.929; the Cronbach's a coefficient of leadership behavior scale is 0.866 . The Cronbach's a coefficient of the employee performance scale is 0.918 , the Cronbach alpha coefficient of task performance scale is 0.908 , the Cronbach a coefficient of is interpersonal facilitation scale is 0.877 , the Cronbach alpha coefficient of job dedication scale is 0.906 . The Cronbach's coefficient of work alienation scale is 0.901 , the Cronbach a coefficient of the monotonousness scale is 0.858 , the Cronbach a coefficient of powerless and nihilism are 0.784 and 0.807 . Thus all Cronbach a coefficient are more than the standard 0.8. It indicated that the questionnaire had good reliability, and it is stable and reliable.

To examine if participants were able to distinguish between the dimensions (i.e., interpersonal facilitation and job dedication), a confirmatory factor analysis (CFA) was conducted using LISREL 8.5. Analysis results are as follows: the standardized loading factor of items of leadership tasks behavior were between 0.50 and 0.87 ; the 
standardized loading factor of items of leadership relational behavior were between 0.50 and 0.64 , the standardized loading factor of items of job performance were between 0.527 and 0.890 ; the standardized loading factor of items of work alienation were between 0.641 and 0.857 . In summary, the subscales selected in this paper have good reliability and validity, which correspond with the previous test results. It can be applied to the formal measurements.

\subsection{Formal Testing}

Data were collected in the study from the employees of the organization in Dalian, China. Among the participants, 210 completed surveys were returned (83.33 percent response rate).

The participants reported that $57 \%$ of the respondents were male, $43 \%$ were female. Addition $6 \%$ reported having a high-school degree or less, $26.5 \%$ reported having a vocational degree, 50\% reported having an undergraduate degree, $17.5 \%$ reported having a master's degree and above. Among the participants, $28.5 \%$ were ordinary employees, $40.0 \%$ were line managers, and $31.5 \%$ were middle managers. Besides that, $46.5 \%$ reported working in the state-owned enterprises, $29 \%$ reported working in the private enterprises, and $24.5 \%$ reported working in the foreign-funded enterprises. In our sample, $26.9 \%$ of the respondents had $1-3$ years of job tenure, $13 \%$ of the respondents had 4 - 6 years of job tenure, $34.5 \%$ of the respondents had 5 - 7 years of job tenure, and $36 \%$ of the respondents had more than 7 years of job tenure. Overall, it made the samples more representative.

\section{Statistical Analysis and Hypothesis Testing}

\subsection{Descriptive Statistics}

The results of statistical analysis (Table 1) most leaders in the respondents had relational behavior, and the mean value of relational behavior was 3.99, which was significantly higher than 3 , the median value of Likert scale. The mean value of task behavior was 2.51 , which was significantly lower than the mean value of relational behavior, and was also lower than the median value of Likert scale. These proved that the degree of leader show task behavior was low.

The mean value of work alienation was 2.25, lower than Likert scale's median value 3 . This proved that staff didn't feel work alienation obviously. The mean value of monotonousness was 2.11; the mean value of powerless was 2.42; the mean value of nihilism was 2.27, all were lower than 3 .

The overall performance level of the respondents was relatively high, with the average of 3.78, higher than Likert scale's median 3. In which the mean value of task performance was 3.60, relationship performance was 3.85, so employees' relational performance was higher than task performance and it proved that employees were more willing to performance behavior on their own initiative which was not specified on work instructions, but can enhance mutual cooperation. Especially interpersonal facilitation behavior in relational performance, and the mean value was 3.90 .

\section{Table 1. Results of descriptive statistics.}

\begin{tabular}{|c|c|c|c|c|c|}
\hline Variables & Mean & S.D. & Coefficient of Variance & Item number & $\mathbf{N}$ \\
\hline Task behavior & 2.5110 & 0.59434 & 0.2367 & 10 & 200 \\
\hline Relational behavior & 3.9945 & 0.59842 & 0.1498 & 10 & 200 \\
\hline Work alienation & 2.2500 & 0.70054 & 0.3114 & 10 & 200 \\
\hline Monotonousness & 2.1125 & 0.79285 & 0.3753 & 4 & 200 \\
\hline Powerless & 2.4167 & 0.82922 & 0.3431 & 3 & 200 \\
\hline Nihilism & 2.2667 & 0.80548 & 0.3554 & 3 & 200 \\
\hline Job performance & 3.7764 & 0.51710 & 0.1369 & 21 & 200 \\
\hline Task performance & 3.6050 & 0.70776 & 0.1963 & 6 & 200 \\
\hline Relational performance & 3.8450 & 0.50449 & 0.1312 & 15 & 200 \\
\hline Interpersonal facilitation & 3.9036 & 0.54440 & 0.1395 & 7 & 200 \\
\hline Job dedication & 3.7938 & 0.60369 & 0.1591 & 8 & 200 \\
\hline
\end{tabular}




\subsection{Correlation Analysis}

We use Pearson correlation coefficient to determine the correlation between variables, and the statistical analysis results were shown in Table 2. From the table we can see the demographic variables related to work alienation were educational background, position and the nature of enterprise, while the demographic variables related to job performance were only educational background and job category. In addition, the correlation coefficient between leadership task behavior and relational behavior and employee alienation, job performance dimensions reached 0.01 significant level.

\subsection{Regression Analysis}

\subsubsection{Regression Analysis of Leadership Behavior Regression and Relational Behavior on Job Performance and Work Alienation}

This paper adopted hierarchical regression method, firstly, put the demographic variables (education, job category or business nature) as the first group of predictor variables into regression equation, then put the leadership task behavior and relational behavior which were get through the treatment center as the second group of predictor variables into the regression equation. The dependent variable were employee work alienation (including three dimensions: monotonousness, powerless and nihilism, the controlled variable are educational background, position and nature of the enterprise) and job performance (including three dimensions: task performance, interpersonal facilitation and job dedication, the controlled variable are educational background and job category), and made independent variables into the way by force.

Results of regression analysis (Table 3) showed: Leadership task behavior and relational behavior on employees' task performance, interpersonal facilitation and job dedication predictive $\Delta \mathrm{R} 2$ values were $0.072,0.033$, $0.083,0.03,0.077,0.089$, and they all have reached a significant level of 0.01 . That proved eliminating the effect of demographic variables on job performance, leadership task behavior had a significant negatively effect on job performance, and leadership relational behavior had a significant positive effect on job performance. Therefore, hypothesis 1 and sub hypothesis, $1 \mathrm{a}$ and $1 \mathrm{~b}, 1 \mathrm{c}, 1 \mathrm{~d}, 1 \mathrm{e}, 1 \mathrm{f}$ were supported.

Leadership task behavior and relational behavior on employees' work alienation (including three dimensions: monotonousness, powerless and nihilism) predictive $\Delta \mathrm{R} 2$ values were $0.097,0.100,0.54,0.001,0.011,0.567$,

Table 2. Results of correlation analysis between variables.

\begin{tabular}{|c|c|c|c|c|c|c|c|c|c|c|c|c|}
\hline Variables & 1 & 2 & 3 & 4 & 5 & 6 & 7 & 8 & 9 & 10 & 11 & 12 \\
\hline \multicolumn{13}{|l|}{ Gender } \\
\hline $\begin{array}{l}\text { Educational } \\
\text { background }\end{array}$ & 0.064 & & & & & & & & & & & \\
\hline Position & 0.045 & $0.488^{* *}$ & & & & & & & & & & \\
\hline Nature & -0.106 & $-0.157^{*}$ & -0.159 & & & & & & & & & \\
\hline $\begin{array}{c}\text { Fixed number } \\
\text { of years }\end{array}$ & -0.006 & 0.011 & -0.086 & 0.037 & & & & & & & & \\
\hline Monotonousness & -0.136 & $-0.736^{* *}$ & $-0.504^{* *}$ & $0.182^{*}$ & 0.007 & & & & & & & \\
\hline Powerless & -0.116 & $-0.663^{* *}$ & $-0.402^{* *}$ & $0.179^{*}$ & 0.06 & $0.587^{* *}$ & & & & & & \\
\hline Nihilism & $-.171^{*}$ & $-0.724^{* *}$ & $-0.337^{* *}$ & $0.180^{*}$ & 0.039 & $0.628^{* *}$ & $0.674^{* *}$ & & & & & \\
\hline Task behavior & -0.079 & $-0.554^{* *}$ & $-0.308^{* *}$ & $0.149^{*}$ & -0.094 & $0.675^{* *}$ & $0.638^{* *}$ & $0.601^{* *}$ & & & & \\
\hline Relational behavior & 0.108 & $0.466^{* *}$ & $0.332^{* *}$ & -0.114 & -0.061 & $-0.388^{* *}$ & $-0.416^{* *}$ & $-0.441^{* *}$ & $-0.383^{* *}$ & & & \\
\hline Task performance & -0.103 & $0.199^{* *}$ & $0.275^{* *}$ & -0.116 & 0.019 & $-0.199^{* *}$ & $-0.189^{* *}$ & $-0.140^{*}$ & $-0.341^{* *}$ & $0.269^{* *}$ & & \\
\hline $\begin{array}{l}\text { Interpersonal } \\
\text { facilitation }\end{array}$ & 0.00 & $0.169^{*}$ & $0.192^{* *}$ & -0.055 & 0.06 & $-0.146^{*}$ & $-0.162^{*}$ & $0.198^{* *}$ & $-0.250^{* *}$ & $0.336^{* *}$ & $0.521^{* *}$ & \\
\hline Job dedication & -0.084 & $0.278^{* *}$ & $0.201^{* *}$ & -0.037 & -0.003 & $-0.284^{* *}$ & $-0.229^{* *}$ & $-0.325^{* *}$ & $-0.396^{* *}$ & $0.400^{* *}$ & $0.628^{* *}$ & $0.528^{* *}$ \\
\hline
\end{tabular}

Note: All coefficients are standardized coefficients. $p^{*}<0.05 ; p^{* *}<0.01 ; p^{* * *}<0.001$. 
Table 3. Hierarchical regression of independent variable on employee work alienation and job performance respectively.

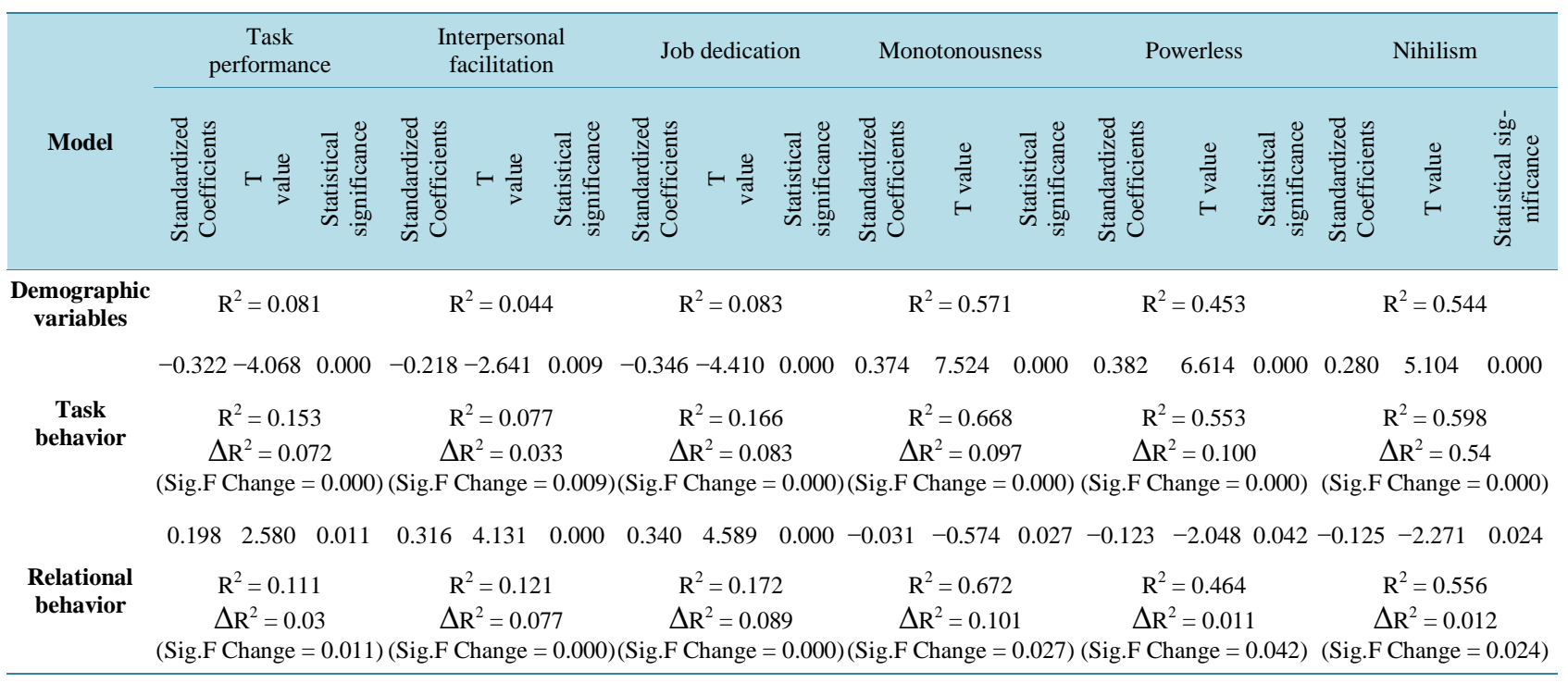

Note: 1$){ }^{*}$ in a significant level of $0.05,{ }^{* *}$ in a significant level of $0.01,{ }^{* * *}$ in a significant level of $0.001 ; 2$ ) The regression coefficient of demographic varia bles was omitted.

and except for the coefficient of task behavioral and monotonousness, the other coefficients had all reached a significant level of 0.05 . That proved eliminating the effect of demographic variables on job performance, leadership relational behavior had a significant positive effect on work alienation, and leadership task behavior had a significant negatively effect on employee' powerless and nihilism. Therefore, hypothesis 2 and sub hypothesis, 2a, 2b, 2c, 2d, 2e and $2 \mathrm{f}$ were supported.

\subsubsection{Regression Analysis of Employee Work Alienation on Job Performance}

Still using hierarchical regression method, the independent variables were monotonousness, powerless and nihilism, the control variables were educational background and job category, the dependent variables was job performance, and the results of regression analysis showed (Table 4): Monotonousness has significant predictive power on task performance, interpersonal facilitation and job dedication at 0.05 level, and the influence direction is negative. Powerless have significant predictive power on task performance, interpersonal facilitation and job dedication at 0.05 level, and the direction is negative. Nihilism has significant predictive power on task performance and interpersonal facilitation at 0.05 level, and the direction is negative; nihilism had no significant predictive power on job dedication. Therefore, hypothesis 3a, 3b, 3c, 3d, 3e and 3f were supported, while hypothesis 3 get some support.

\subsection{Analysis of the Mediation}

According to the method of testing the mediation proposed by Baron \& Kenney (1968) and reference to the method of testing the mediating effects proposed by Zhonglin Wen (2004), this paper tested the mediation of work alienation between leadership style and job performance through the following steps: First, test whether the relationship between leadership style and job performance was significant; Second, test whether the relationship between leadership style and work alienation was significant; Finally, test whether the relationship between work alienation and job performance was significant.

Through the regression analysis we can know that task behavior(independent variable) was significantly correlated with task performance (dependent variable), and task behavior (independent variable) was significantly correlated with powerless(mediating variables).So, we just need to examine whether the powerless(mediating variables) had a significant influence on task performance (dependent variable) and whether task behavior(independent variable) was still significantly correlated with task performance (dependent variable) when powerless (mediating variables) was entered as a mediator in regression equation of task behavior (independent variable) and task performance (dependent variable). 
Table 4. Hierarchical regression of employee work alienation on job performance.

\begin{tabular}{|c|c|c|c|c|c|c|c|c|c|}
\hline \multirow{2}{*}{ Model } & \multicolumn{3}{|c|}{ Task performance } & \multicolumn{3}{|c|}{ Interpersonal facilitation } & \multicolumn{3}{|c|}{ Job dedication } \\
\hline & $\begin{array}{l}\text { Standardized } \\
\text { Coefficients }\end{array}$ & $\begin{array}{c}\mathrm{T} \\
\text { value }\end{array}$ & $\begin{array}{l}\text { Statistical } \\
\text { significance }\end{array}$ & $\begin{array}{l}\text { Standardized } \\
\text { Coefficients }\end{array}$ & $\begin{array}{c}\mathrm{T} \\
\text { value }\end{array}$ & $\begin{array}{c}\text { Statistical } \\
\text { significance }\end{array}$ & $\begin{array}{l}\text { Standardized } \\
\text { Coefficients }\end{array}$ & $\begin{array}{c}\mathrm{T} \\
\text { value }\end{array}$ & $\begin{array}{l}\text { Statistical } \\
\text { significance }\end{array}$ \\
\hline $\begin{array}{l}\text { Demographic } \\
\text { variables }\end{array}$ & \multicolumn{3}{|c|}{$\mathrm{R}^{2}=0.081$} & \multicolumn{3}{|c|}{$\mathrm{R}^{2}=0.021$} & \multicolumn{3}{|c|}{$\mathrm{R}^{2}=0.083$} \\
\hline $\mathbf{F}$ & \multicolumn{3}{|c|}{$5.478^{* *}$} & \multicolumn{3}{|c|}{$2.435^{*}$} & \multicolumn{3}{|c|}{$8.909^{* * *}$} \\
\hline Monotonousness & -0.190 & -1.950 & 0.046 & -0.146 & -2.077 & 0.039 & -0.257 & -2.400 & 0.017 \\
\hline Powerless & -0.268 & -2.427 & 0.017 & -0.162 & -2.307 & 0.022 & -0.103 & -1.976 & 0.049 \\
\hline Nihilism & -0.298 & -2.624 & 0.010 & -0.203 & -2.872 & 0.005 & -0.037 & -0.379 & 0.705 \\
\hline \multirow[t]{2}{*}{$\mathbf{F}$} & \multicolumn{3}{|c|}{$4.775^{* * *}$} & \multicolumn{3}{|c|}{$4.124^{*}$} & \multicolumn{3}{|c|}{$5.319^{* * *}$} \\
\hline & \multicolumn{3}{|c|}{$\begin{array}{c}\mathrm{R}^{2}=0.164 \\
\Delta \mathrm{R}^{2}=0.083 \\
\text { (Sig.F Change }=0.009 \text { ) }\end{array}$} & \multicolumn{3}{|c|}{$\begin{array}{c}\mathrm{R}^{2}=0.040 \\
\Delta \mathrm{R}^{2}=0.019 \\
\text { (Sig.F Change }=0.005 \text { ) }\end{array}$} & \multicolumn{3}{|c|}{$\begin{array}{c}\mathrm{R}^{2}=0.121 \\
\Delta \mathrm{R}^{2}=0.038 \\
(\text { Sig. } \mathrm{F} \text { Change }=0.043)\end{array}$} \\
\hline
\end{tabular}

Note: 1 ) ${ }^{*}$ in a significant level of $0.05,{ }^{* *}$ in a significant level of $0.01,{ }^{* * *}$ in a significant level of $\left.0.001 ; 2\right)$ The regression coefficient of demographic variables was omitted.

As is seen in Table 5, significant relationships were observed between powerless and task performance at the $p<0.05$ level after we add powerless into the regression equation of task behavior and task performance, and significant relationships were observed between task behavior and task performance at the $p<0.001$ level. Therefore, powerless partially mediated the relationship between task behavior and task performance.

Simultaneously, we added powerless into the regression equation of task behavior and inter personal facilitation. The results showed that there were significant relationships between powerless and interpersonal facilitation at the $p<0.05$ level after we added powerless into the equation of task behavior and interpersonal facilitation, and significant relationships were observed between task behavior and interpersonal facilitation at the $p<$ 0.05 level. Therefore, powerless partially mediated the relationship between task behavior and interpersonal facilitation.

In the same way, we added powerless into the regression equation of task behavior and job dedication. The results showed that there were significant relationships between powerless and job dedication at the $p<0.05$ level after we added powerless into the equation of task behavior and interpersonal facilitation, and significant relationships were observed between task behavior and job dedication at the $p<0.001$ level. Therefore, powerless partially mediated the relationship between task behavior and job dedication.

By this way, we added other dimensions of work alienation into the regression equations of task behavior and relational behavior with other dimensions of job performance. The results showed that nihilism partially mediated the relationship between task behavior and task performance, interpersonal facilitation; Monotonousness partially mediated the relationship between task behavior and task performance, interpersonal facilitation, job dedication. Nihilism partially mediated the relationship between relational behavior and task performance, interpersonal facilitation; Powerless fully mediated the relationship between relational behavior and task performance, interpersonal facilitation, and partially mediated the relationship between relational behavior and job dedication; Monotonousness partially mediated the relationship between relational behavior and task performance, interpersonal facilitation, job dedication.

In the examination of the mediating role that nihilism played between task behavior and job dedication, relational behavior and job dedication, the results showed that nihilism was not significantly related to job dedication, so we need to do Sobel test. The result was shown in Table 6. We can know that nihilism did not mediate the relationship between task behavior and job dedication or relational behavior and job dedication. In summary, H4, H4c, H4f were partially supported by the data, and H4a, H4b, H4d, H4e were supported by the data. 
Table 5. Analysis of mediating results of powerless between task behavior and job performance.

\begin{tabular}{|c|c|c|c|c|c|c|c|c|c|}
\hline \multirow{2}{*}{ Model } & \multicolumn{3}{|c|}{ Task performance } & \multicolumn{3}{|c|}{ Interpersonal facilitation } & \multicolumn{3}{|c|}{ Job dedication } \\
\hline & $\begin{array}{l}\text { Standardized } \\
\text { coefficients }\end{array}$ & $\begin{array}{c}\mathrm{T} \\
\text { value }\end{array}$ & $\begin{array}{l}\text { Statistical } \\
\text { significance }\end{array}$ & $\begin{array}{l}\text { Standardized } \\
\text { coefficients }\end{array}$ & $\begin{array}{c}\mathrm{T} \\
\text { value }\end{array}$ & $\begin{array}{l}\text { Statistical } \\
\text { significance }\end{array}$ & $\begin{array}{c}\text { Standardized } \\
\text { coefficients }\end{array}$ & T value & $\begin{array}{l}\text { Statistical } \\
\text { significance }\end{array}$ \\
\hline $\begin{array}{c}\text { Task } \\
\text { behavior }\end{array}$ & -0.295 & -3.712 & 0.000 & -0.168 & -2.071 & 0.040 & -0.295 & -3.851 & 0.000 \\
\hline $\begin{array}{c}\text { Relational } \\
\text { behavior }\end{array}$ & -0.254 & -4.452 & 0.000 & -0.186 & -1.975 & 0.049 & -0.285 & -3.700 & 0.000 \\
\hline Powerless & -0.153 & -2.031 & 0.048 & -0.046 & -2.143 & 0.035 & -0.120 & -2.255 & 0.030 \\
\hline
\end{tabular}

Note: The regression coefficient of demographic variables was omitted.

Table 6. The result of sobel test.

\begin{tabular}{ccccc}
\hline Independent variable & Mediating variables & Consequences of variables & $\mathrm{Z}$ & $\mathrm{P}$ (Two-tailed) \\
\hline Task behavior & Nihilism & Job dedication & -1.330 & 0.183 \\
Relational behavior & Nihilism & Job dedication & -1.716 & 0.086 \\
\hline
\end{tabular}

\section{Conclusion and Discussion}

\subsection{Conclusion}

Employees in China were taken as an object of the study to find out the influence of leaders' task behavior and relational behavior on job performance, and the mediating effects of work alienation was verified at the same time. The results revealed that part of the demographic variables had effects on work alienation and job performance. Sex, educational background, positions, nature of enterprise were significantly related to work alienation at $p<$ 0.01 level; Educational background and positions were significantly related to job performance at $p<0.01$ level, while nature of enterprise was significantly related to job performance at $p<0.05$ level. There was a significant negative correlation between leaders' task behavior and job performance, while relational behavior was significantly positive correlated with job performance. The relationship between leaders' task behavior and relational behavior was mediated by work alienation. Monotonousness and powerless partially mediated the relationship between task behavior and three dimensions of job performance, such as task performance, interpersonal facilitation and job dedication. While nihilism partially mediated the relationship between task behavior and three dimensions of job performance except job dedication. Monotonousness has a partially mediation role in the relationship between relational behavior and three dimensions of job performance, too. The relationship between relational behavior and two dimensions of job performance including task performance and interpersonal facilitation was fully mediated by powerless, but there was only a partially mediating effect of powerless in the relationship between relational behavior and job dedication. As for nihilism, it played a partially mediate role between relational behavior and dimensions of job performance except job dedication. In other words, nihilism had no mediating effects on the relationships between task performance and job dedication or the relationships between relational behavior and job dedication.

\subsection{Discussion}

1) The structure of job performance. Scholars in different periods had make definitions of performance from angles of results, abilities, behaviors, as well as the value, respectively, since 1970s. Kane (1996) [36] regarded performance as a kind of results which can record employees' work and their performance. While some of scholars think that performance is a kind of behavior rather than a result (Campbell, McCloy, Oppler, 1993) [37]. These behaviors were related to the goals of organization or the department or team which the employee is in (Murphy, 1989) [38]. In fact, performance has both positive and negative effects on production. Questionnaires were created and distributed to engineers, Borman and Motowidlo (1993) [39] first proposed the concept of contextual performance and task performance by making an empirical study. Task performance was defined as behaviors which made directly contributions to the core of organizations technology, including activities that were 
usually regarded as employees’ work (Coleman and Borman, 2000) [40]. Contextual performance was defined as widely social environment behaviors that kept the core technology working (Borman and Motowidlo, 1993) [39]. For example, volunteering for extra work, doing some work which is not required, supporting employees and organizations, etc. Employees' personal work can be promoted by those voluntary and positive behaviors and attitudes, thus actualizing the effective operation in organization. Task performance and contextual performance can be respectively achieved by core technology and staffs' voluntary behaviors which are conducive to organizations additional.

Task performance and contextual performance are two important aspects to value job performance, and task performance varies with different positions while contextual performance is more depended on staffs personal factors rather than the significantly effects by positions [41]. Contextual performance, in practice, will influence subjective evaluation of leaders to employees. Good behaviors of employees will be more likely to due to the employees themselves by their leaders, while bad behaviors or results are attributed to environment if leaders and staffs have a closely relationship. If it is not, the situation is reverse (Befort and Hattrup, 2003) [42].

The division of task and contextual performance proposed by Borman and Motowidlo has been widely accepted in academic field. It is supported by later empirical study either. Most of present works begin with it [43]. So we valued job performance by task performance and contextual performance in this paper.

2) Leadership task behavior and relational behavior. Leadership style of managers has been studied more in the research field of leadership theory and it is relatively mature. Transactional and transformational leadership are two kinds of popular leadership styles at present. However, both of them are the change of leadership behaviors with the aim of leadership style matches with the environment around. They are combinations in different degrees of care about human or task. So the leaders react with different situations is really based on the understanding of the two most basic behaviors' combinations of leadership styles. Though studies about leadership styles and job performance have obtained a number of research achievements, this paper chose task behavior and relational behavior as variables, which can represent leadership style in nature, to study the mediating role of work alienation in the relationship of job performance and behaviors still have unique meanings for managers and staffs.

\subsection{Limitations and Future Research}

This paper constructed a relational model of task behavior and relational behavior with work alienation and job performance. We did an empirical research and made mechanism of task behavior, relational behavior and task performance clearly. There are three limitations of the study followed.

1) Due to the containing of sensitive variables in the paper, such as task behavior, relational behavior, job performance and so on, we did more strict selections to choose the samples. On the other hand, to avoid same-source common method variance and guarantee the authenticity and accuracy of data, the data were analyzed by paired samples in this article. It was a challenge to enlarge sample size to some extent so that we didn’t have enough valid samples.

2) Questionnaire survey was the mainly method in this paper, but we couldn’t accurately judge the leading behaviors of leaders and work alienation of employees through it.

3) It is a complex process for leadership behavior to influence job performance. There are other variables exist, except work alienation, which may mediate or regulate the relationship between leadership behavior and job performance. Owing to space constraints, this paper tested only the mediation of work alienation.

We encourage future research to enlarge sample size so that the accuracy and credibility of the sample data can be improved and the survey results will be more convictive. It should be combined with questionnaires, interviews and other methods to test leadership behavior and work alienation in the future research. We can avoid measurement errors caused by psychological self-protection and improve the accuracy of measurement through it. Another direction for future research is to uncover additional variables, except work alienation, that have effects on the relationship between leadership behavior and job performance to enrich the mechanism of how leadership behavior influence job performance.

\section{References}

[1] Hall, D.T. (1976) Careers in Organizations. Goodyear Pub. Co.

[2] Arthur, M.B. (1994) The Boundaryless Career: A New Perspective for Organizational in Inquiry. Journal of Organizational Behavior, 15, 295-306. http://dx.doi.org/10.1002/job.4030150402 
[3] Briscoe, J.P., Hall, D.T. and DeMuth, R.L.F. (2006) Protean and Boundaryless Careers: An Empirical Exploration. Journal of Vocational Behavior, 69, 30-47. http://dx.doi.org/10.1016/j.jvb.2005.09.003

[4] Rousseau, D.M. (1989) Psychological and Implied Contracts in Organizations. Employee Responsibilities and Rights Journal, 2, 121-139. http://dx.doi.org/10.1007/BF01384942

[5] Banai, M., Reisel, W.D. and Probst, T.M. (2004) A Managerial and Personal Control Model: Predictions of Work Alienation and Organizational Commitment in Hungary. Journal of International Management, 10, 375-392. http://dx.doi.org/10.1016/j.intman.2004.05.002

[6] Nair, N. and Vohra, N. (2010) An Exploration of Factors Predicting Work Alienation of Knowledge Workers. Management Decision, 48, 600-615. http://dx.doi.org/10.1108/00251741011041373

[7] Kanungo, R.N. (1982) Measurement of Job and Work Involvement. Journal of Applied Psychology, 67, 341-349. http://dx.doi.org/10.1037/0021-9010.67.3.341

[8] Rauch, C.F. and Behling, O. (1984) Functionalism: Basis for an Alternate Approach to the Study of Leadership. Leaders and Managers: International Perspectives on Managerial Behavior and Leadership, 45-62. http://dx.doi.org/10.1016/B978-0-08-030943-9.50012-7

[9] Eisenberger, R., Fasolo, P. and Davis-LaMastro, V. (1990) Perceived Organizational Support and Employee Diligence, Commitment, and Innovation. Journal of Applied Psychology, 75, 51-59. http://dx.doi.org/10.1037/0021-9010.75.1.51

[10] Shi, H.Y. (2012) Study on the Model of Organizational Identity and Contextual Performance. Science \& Technology Vision, 28, 90.

[11] Bowers, D.G. and Seashore, S.E. (1966) Predicting Organizational Effectiveness with a Four-Factor Theory of Leadership. Administrative Science Quarterly, 238-263. http://dx.doi.org/10.2307/2391247

[12] Hui, C., Lee, C. and Rousseau, D.M. (2004) Employment Relationships in China: Do Workers Relate to the Organization or to People? Organization Science, 15, 232-240. http://dx.doi.org/10.1287/orsc.1030.0050

[13] Meyer, J.P., Allen, N.J. and Smith, C.A. (1993) Commitment to Organizations and Occupations: Extension and Test of a Three-Component Conceptualization. Journal of Applied Psychology, 78, 538-551. http://dx.doi.org/10.1037/0021-9010.78.4.538

[14] Riketta, M. (2002) Attitudinal Organizational Commitment and Job Performance: a Meta-Analysis. Journal of Organizational Behavior, 23, 257-266. http://dx.doi.org/10.1002/job.141

[15] Shapiro, D.L., Sheppard, B.H. and Cheraskin, L. (1992) Business on a Handshake. Negotiation Journal, 8, $365-377$. http://dx.doi.org/10.1111/j.1571-9979.1992.tb00679.x

[16] Rousseau, D.M., Sitkin, S.B., Burt, R.S. and Camerer, C. (1998) Not So Different after All: A Cross-Discipline View of Trust. Academy of Management Review, 23, 393-404. http://dx.doi.org/10.5465/AMR.1998.926617

[17] Sarros, J.C., Tanewski, G.A., Winter, R.P., Santora, J.C. and Densten, I.L. (2002) Work Alienation and Organizational Leadership. British Journal of Management, 13, 285-304. http://dx.doi.org/10.1111/1467-8551.00247

[18] Hall, G.B., Dollard, M.F., Tuckey, M.R., Winefield, A.H. and Thompson, B.M. (2010) Job Demands, Work-Family Conflict, and Emotional Exhaustion in Police Officers: A Longitudinal Test of Competing Theories. Journal of Occupational and Organizational Psychology, 83, 237-250. http://dx.doi.org/10.1348/096317908X401723

[19] Ramaswami, S.N., Agarwal, S. and Bhargava, M. (1993) Work Alienation of Marketing Employees: Influence of Task, Supervisory, and Organizational Structure Factors. Journal of the Academy of Marketing Science, 21, 179-193. http://dx.doi.org/10.1177/0092070393213002

[20] Banai, M. and Weisberg, J.Y. (2003) Alienation in State-Owned and Private Companies in Russia. Scandinavian Journal of Management, 19, 359-383. http://dx.doi.org/10.1016/S0956-5221(02)00005-2

[21] Banai, M. and Hu, J. (2003) Leadership and Alienation in State-Owned Enterprises and International Joint Ventures in China. In: Alon, I., Ed., Chinese Economic Transition and International Marketing Strategy, Praeger Publishing, Westport, 237-249.

[22] Judge, T.A., Locke, E.A. and Durham, C.C. (1997) The Dispositional Causes of Job Satisfaction: A Core Evaluations Approach. Research in Organizational Behavior, 19, 151-188.

[23] Lukes, S. (1977) Alienation and Anomie. In: Lukes, S., Ed., Essays in Social Theory, Macmillan Education UK, London, 74-95. http://dx.doi.org/10.1007/978-1-349-15729-7_4

[24] Butler, A., Grzywacz, J., Bass, B. and Linney, K. (2005) Extending the Demands-Control Model: A Daily Diary Study of Job Characteristics, Work-Family Conflict and Work-Family Facilitation. Journal of Occupational and Organizational Psychology, 78, 155-169. http://dx.doi.org/10.1348/096317905X40097

[25] Bateman, T.S. and Organ, D.W. (1983) Job Satisfaction and the Good Soldier: The Relationship between Affect and Employee “Citizenship”. Academy of Management Journal, 26, 587-595. http://dx.doi.org/10.2307/255908 
[26] Schuhmann, W., Schwaninger, M. and Bilello, U. (1996) Organizational Transformation and Learning: A Cybernetic Approach to Management. Wiley, Chichester.

[27] Powell, W.E. (1994) The Relationship between Feelings of Alienation and Burnout in Social Work. Families in Society, 75, 229-235.

[28] Hirschfeld, R.R., Feild, H.S. and Bedeian, A.G. (2000) Work Alienation as an Individual-Difference Construct for Predicting Workplace Adjustment: A Test in Two Samples. Journal of Applied Social Psychology, 30, 1880-1902. http://dx.doi.org/10.1111/j.1559-1816.2000.tb02473.x

[29] Armstrong-Stassen, M. (2006) Determinants of How Managers Cope with Organizational Downsizing. Applied Psychology, 55, 1-26. http://dx.doi.org/10.1111/j.1464-0597.2006.00225.x

[30] Salanova, M., Agut, S. and Peiró, J.M. (2005) Linking Organizational Resources and Work Engagement to Employee Performance and Customer Loyalty: The Mediation of Service Climate. Journal of Applied Psychology, 90, 1217-1227. http://dx.doi.org/10.1037/0021-9010.90.6.1217

[31] Huang, Y.C. (2006) The Relationships among Job Satisfaction, Professional Commitment, Organizational Alienation, and Coaching Efficacy of School Volleyball Coaches in Taiwan. ProQuest.

[32] Kanungo, R.N. and Misra, S. (1992) Managerial Resourcefulness: A Reconceptualization of Management Skills. Human Relations, 45, 1311-1332. http://dx.doi.org/10.1177/001872679204501204

[33] DiPietro, R.B. and Pizam, A. (2007) Employee Alienation in the Quick Service Restaurant Industry. Journal of Hospitality \& Tourism Research, 32, 22-39. http://dx.doi.org/10.1177/1096348007309567

[34] Northouse, P.G. (2015) Leadership: Theory and Practice. Sage Publications, Thousand Oaks.

[35] Mulford, C., Waldner-Haugrud, L. and Gajbhiye, H. (1993) Variables Associated with Agricultural Scientists’ Work Alienation and Publication Productivity. Scientometrics, 27, 261-282. http://dx.doi.org/10.1007/BF02016942

[36] Kane, J.S. (1996) The Conceptualization and Representation of Total Performance Effectiveness. Human Resource Management Review, 6, 123-145. http://dx.doi.org/10.1016/S1053-4822(96)90016-9

[37] Campbell, J.P., McCloy, R.A., Oppler, S.H. and Sager, C.E. (1993) A Theory of Performance. In: Schmitt, N. and Borman, W.C., Eds., Personnel Selection in Organizations, Jossey-Bass, San Francisco, 3570.

[38] Murphy, K.R. and Kroeker, L.P. (1988) Dimensions of Job Performance. Colorado State University, Fort Collins.

[39] Borman, W.C. and Motowidlo, S.M. (1993) Expanding the Criterion Domain to Include Elements of Contextual Performance. In: Schmitt, N. and Borman, W.C., Eds., Personnel Selection in Organizations, Jossey-Bass, San Francisco, 71-98.

[40] Coleman, V.I. and Borman, W.C. (2000) Investigating the Underlying Structure of the Citizenship Performance Domain. Human Resource Management Review, 10, 25-44. http://dx.doi.org/10.1016/S1053-4822(99)00037-6

[41] Borman, W.C. and Motowidlo, S.J. (1997) Task Performance and Contextual Performance: The Meaning for Personnel Selection Research. Human Performance, 10, 99-109. http://dx.doi.org/10.1207/s15327043hup1002_3

[42] Befort, N. and Hattrup, K. (2003) Valuing Task and Contextual Performance: Experience, Job Roles, and Ratings of the Importance of Job Behaviors. Applied HRM Research, 8, 17-32.

[43] Zhou, H. (2011) Effect of Psychological Capital on Task Performance and Contextual Performance. Forum on Science and Technology in China, No. 7, 122-128. 